\title{
Frequency distribution of the methylenetetrahydrofolate reductase polymorphisms in sickle cell hemoglobinopathy-A hospital based study in central India
}

\author{
Suprava Patel ${ }^{\mathrm{a},{ }^{*},}$, Rachita Nanda ${ }^{\mathrm{a}}$, Nighat Hussain ${ }^{\mathrm{b}}$, Eli Mohapatra ${ }^{\mathrm{a}}$, Pradeep K. Patra ${ }^{\mathrm{c}}$ \\ ${ }^{a}$ Department of Biochemistry, All India Institute of Medical Sciences, Raipur, Chhattisgarh, India \\ ${ }^{\mathrm{b}}$ Department of Pathology, All India Institute of Medical Sciences, Raipur, Chhattisgarh, India \\ ${ }^{\mathrm{c}}$ Department of Biochemistry, Chhattisgarh Institute of Medical Sciences, Bilaspur, Chhattisgarh, India
}

\section{A R T I C L E I N F O}

\section{Keywords:}

C677T

A1298C

Children

Ethnicity

Anemia

Chhattisgarh

\begin{abstract}
A B S T R A C T
Background: Coexistence of polymorphisms of methylenetetrahydrofolate reductase (MTHFR) with sickle cell gene exerts synergistic effect on complications associated with sickle cell hemoglobinopathy. Therefore, the study was planned to determine the frequency distribution of the MTHFR C677T and A1298C genotypes in children diagnosed with sickle cell disease.

Methods: A total of 249 children diagnosed with sickle cell anemia, between age group 5-18 years, were enrolled for the cross sectional study. The demographic and clinical details were entered in a structured questionnaire. Collected blood samples were analyzed for hemoglobin and DNA was extracted for genotypic assay for MTHFR C677T and A1298C single nucleotide polymorphisms (SNPs) by Real-time PCR.

Results: The study groups comprised of 218 sickle cell trait (SCT) and 31 sickle cell disease (SCD) children. The caste distribution between the two study groups was quite uniform $\left(\mathrm{X}^{2}{ }_{31}=44.21, \mathrm{p}=0.06\right)$. Frequencies of homozygous mutants 677 TT and $1298 \mathrm{CC}$ were $2 \%$ and $19.7 \%$ respectively. The odds for the variant forms for both SNPs were found to be greater in SCD group. The genotypic and allelic frequencies did not reveal any caste preponderance. The mean age $(\mathrm{p}=0.001)$, weight $(\mathrm{p}<0.001)$, height $(\mathrm{p}<0.001)$, BMI $(\mathrm{p}<0.001)$ and hemoglobin concentrations ( $\mathrm{p}=0.002$ ) were lower in homozygous 1298CC but not so in 677TT children. A1298C also depicted significant association with BMI and anemia ( $<0.001)$.

Conclusion: Homozygous mutant MTHFR variants would be essential genetic markers especially in children with SCD to identify the vulnerable group who frequently get hospitalized for vascular complications.
\end{abstract}

\section{Introduction}

Various clinical studies have documented higher prevalence of hemolytic crisis and severe grade anemia in individuals with homozygous sickle cell hemoglobinopathy, especially in children. An additional association of genetic polymorphism related to enzyme involved in metabolism of folic acid and vitamin B12, like methylenetetrahydrofolate reductase (MTHFR) would have synergistic effect on the complications associated with sickle cell disorder. ${ }^{1-3}$ Sickle cell hemoglobinopathy prevalence vary from 2 to $34 \%$ in India, ${ }^{1}$ however, it is of major public health concern in this region of Central India with an overall reported prevalence of $9.3 \%$ HbAS sickle cell trait and $0.21 \%$ homozygous HbSS, and majorly in the tribal population. Nearly $32 \%$ of the population of this state accommodates the tribal communities living in remote catchment areas with much lesser health care facilities. ${ }^{4}$ Co-existence of the MTHFR single nucleotide polymorphisms (SNPs) along with sickle cell gene in these communities would immensely affect the morbidity and mortality due to crisis events associated with the disorder. Hence, it would be of utmost importance to understand the distribution of these SNPs in the population and in various ethnic groups to understand the socio-demographic interaction with the genetic polymorphisms. Screening for these genetic markers would aid in identification of high risk groups for effective modifications in treatment modalities.

Considering the said facts, the study was planned to determine the prevalence percentages of MTHFR C677T and A1298C genotypes and

\footnotetext{
* Corresponding author.

E-mail addresses: dr_suprava@yahoo.co.in (S. Patel), dr.rachitananda@gmail.com (R. Nanda), hussain.nighat@gmail.com (N. Hussain), elimohapatra2011@ gmail.com (E. Mohapatra), pkp1964@yahoo.co.in (P.K. Patra).
} 
the alleles in children of sickle cell hemoglobinopathy. The secondary objective was to determine the frequency distribution of the alleles and combined haplotypes among the various castes and association of the variant genotypes with general characteristics of the study group.

\section{Materials and methods}

A total of 249 children between age group 5-18 years, were enrolled for this cross sectional study. As per Jain et al. study, ${ }^{1}$ the sickle cell gene prevalence in India ranges from $2 \%$ to $34 \%$. Taking the average, prevalence (p) of $18 \%$ was considered for sample size (n) calculation with $5 \%$ margin of error (e) and $\mathrm{Z}=1.96$ at $95 \%$ of confidence interval. Using the Cochran's formula, $\mathrm{n}=\mathrm{Z}^{2 *} \mathrm{p}(1-\mathrm{p}) / \mathrm{e}^{2}$, the sample size calculated was 227. Expecting that there would be some non-responding and refusal for participation during questionnaire session, further, $10 \%(\mathrm{n}=23)$ was added and a total sample size of $227+23=250$ was set at $5 \%$ level of significance, out of which 249 subjects were enrolled during the 12 months of study period. Purposive sampling method was adopted for enrollment with a maximum of 10 subjects per session.

Diagnosed cases of sickle cell hemoglobinopathy attending the outpatient clinics and in-patient wards of our institute were included for the study. Parents/legal guardians not providing consent, any children with history of blood transfusions within last three months and those with non-confirmatory reports and incomplete records were excluded. The heterozygous (HbAS) cases were considered as sickle cell trait (SCT) and the homozygous (HbSS) as sickle cell disease group (SCD). Institutional Ethics Committee approval was obtained and written Informed consent from the parents/legal guardians were obtained for enrollment of the children for the study. All children were demographically and clinically evaluated and details were entered in a structured questionnaire. The weight in kilogram $(\mathrm{Kg})$, height in centimeter $(\mathrm{cm})$ and body mass index (BMI) of the children were calculated in percentile against the age in years (yrs) from Clinical Growth Charts by National Center for Health Statistics made available by Centers for Disease Control and Prevention (CDC) at cdc. gov/growthcharts/clinical_charts.htm.

Blood sample was collected in ethylenediaminetetraacetic acid (EDTA) vacutainer for hemoglobin estimation and deoxyribonucleic acid (DNA) extraction. Blood hemoglobin (Hb) was analyzed in XP-100 Fully Automated hematology Analyzer, Sysmex. Hemoglobin levels above $11 \mathrm{Gm} / \mathrm{dL}$ was considered normal for these children. Values within $7-11 \mathrm{Gm} / \mathrm{dL}$ was considered as mild to moderate grade anemia and values below $7 \mathrm{gm} / \mathrm{dL}$ as severe grade anemia. ${ }^{5,6}$

Following hemoglobin estimation the blood was stored at $2^{\circ}$ to $8{ }^{\circ} \mathrm{C}$ until DNA was extracted on weekly basis using Invitrogen ${ }^{\mathrm{TM}}$ PureLink ${ }^{\mathrm{TM}}$ Genomic DNA Mini kit from ThermoFisher Scientific. After extraction, the DNA samples were stored at $-80{ }^{\circ} \mathrm{C}$ until processed for real-time polymerase chain reaction (PCR) performed on CFX96 real time PCR system, Biorad using TaqMan based Human SNP Genotyping Real-time Assay Kit from Applied Biosystems, ThermoFisher. The three genotypic forms homozygous wild, heterozygous variant and homozygous mutant forms were respectively 677CC, 677CT \& C677TT for C677T SNP and 1298AA, 1298AC and 1298CC for A1298C.

\subsection{Statistical analysis}

The continuous variables were expressed as mean with standard deviation (SD). Comparison of quantitative data between the two study groups was done using independent $t$-test and among the genotypes using analysis of variance (ANOVA). The genotypic frequencies of the two polymorphisms were evaluated for Hardy-Weinberg Equilibrium (HWE) using Goodness of fit, Chi-square test $(\chi 2)$. Distribution of general characteristics, the frequency distribution of the genotypes and alleles with the groups and among the different castes were evaluated using Chi-square test and odds ratio (OR) with 95\% confidence interval (95\%CI), wherever applicable. The alleles $677 \mathrm{C}$ and $1298 \mathrm{~A}$ were noted as wild alleles and 677T and 1298Cas mutant alleles. Combined haplotypes were created by combining one allele of both C677T and A1298C to understand the interaction of the variant forms within the study population. The four combined haplotypes were wild 677C/ 1298A, variant 677C/1298C \& 677T/1298A and mutant.

677T/1298C haplotypes. Data was analyzed using IBM@SPSS 20 software and statistical significance. The values are marked * for those which were found statistically significant at $\mathrm{p}<0.05$ and $\chi^{2}$ df denoted the Chi-square value with degree of freedom.

\section{Results}

The study population included 249 children diagnosed with sickle cell hemoglobinopathy of which 218 children were grouped under SCT and 31 children were grouped under SCD.

\subsection{Distribution of various caste and communities in the study groups}

Caste distribution between the two study groups, SCT and SCD, did not reveal significant association $\left(\chi_{31}^{2}=44.21, \mathrm{p}=0.06\right.$ ) (Fig. 1 ). Altogether, the enrolled children belonged to 32 different caste and communities. The major community documented in this study was Teli (49.4\%) followed by Ganda (7.6\%), Gond (7.2\%), Rauat (7.2\%), and Satnami $(5.2 \%)$. The frequency of other caste and communities ranged from $0.4 \%$ to $3.2 \%$.

\subsection{Characteristics of the study population}

The general characteristics of the study groups are outlined in Table 1 . The sickle cell status of the children neither depicted any dependency with the age factor nor it showed any significant gender difference $\left(\chi_{1}^{2}=0.01, \mathrm{p}=0.91\right.$ and $\left.\chi^{2}{ }_{1}=2.32, \mathrm{p}=0.13\right)$. However, the proportion of females in SCD group who had attended our hospital for treatment purpose was higher than the males. The children of the two groups depicted significant differences between weight $(\mathrm{p}=0.001)$, height $(\mathrm{p}<0.001)$ and BMI $(\mathrm{p}=0.006)$. More than $90 \%$ of the children enrolled under.

SCD group had BMI below 25th percentile. The enrolled children revealed a significantly higher percentage $(87.1 \%)$ of anemia in SCD group $\left(\chi_{2}^{2}=7.3, p=0.026\right)$. Nearly $80 \%$ of the SCD children had mild to moderate anemia as against $57.8 \%$ in SCT children.

\subsection{Comparison of variables between the two groups}

As illustrated in Fig. 2, the mean (SD) of weight ( $\mathrm{p}=0.004)$, height ( $p=0.001)$ and hemoglobin levels $(p=0.04)$ were found to be significantly lower in SCD children than the SCT children. The mean BMI was almost equivalent in children of both the groups $(\mathrm{p}>0.05)$.

\subsection{Frequency distribution of MTHFR C677T and A1298C genotypes in the study population}

The frequency of MTHFR genotypes, C677T and A1298C SNPs in the study population followed HWE and did not deviate from expected equilibrium ( $\mathrm{p}=0.95$ for $\mathrm{C} 677 \mathrm{~T}$ and $\mathrm{p}=0.99$ for $\mathrm{A} 1298 \mathrm{C}$ ). Frequencies of homozygous mutants 677TT and 1298CC were $2 \%$ and $19.7 \%$ respectively as shown in Table 2. No significant differences in genotypic distribution was observed between the study groups for either of the polymorphisms ( $\mathrm{p}=0.19$ for C677T and $\mathrm{p}=0.08$ for A1298C). However, the odds for the variant forms for both SNPs were found to be greater than the wild genotypes in the SCD group when compared to the SCT group.

The frequency distribution of the genotypes of MTHFR polymorphisms did not reveal any caste preferences as shown in table $\mathrm{supp}_{1} 1$ ( $\mathrm{p}=0.87$ for $\mathrm{C} 677 \mathrm{~T}$ and $\mathrm{p}=0.39$ for $\mathrm{A} 1298 \mathrm{C}$ ). The 677TT variant was more prevalent in Teli (60\%), Satnami (20\%) and Rajputs (20\%). That of 1298CC genotype was prevalent in Teli (42.9\%) followed by Rauat 


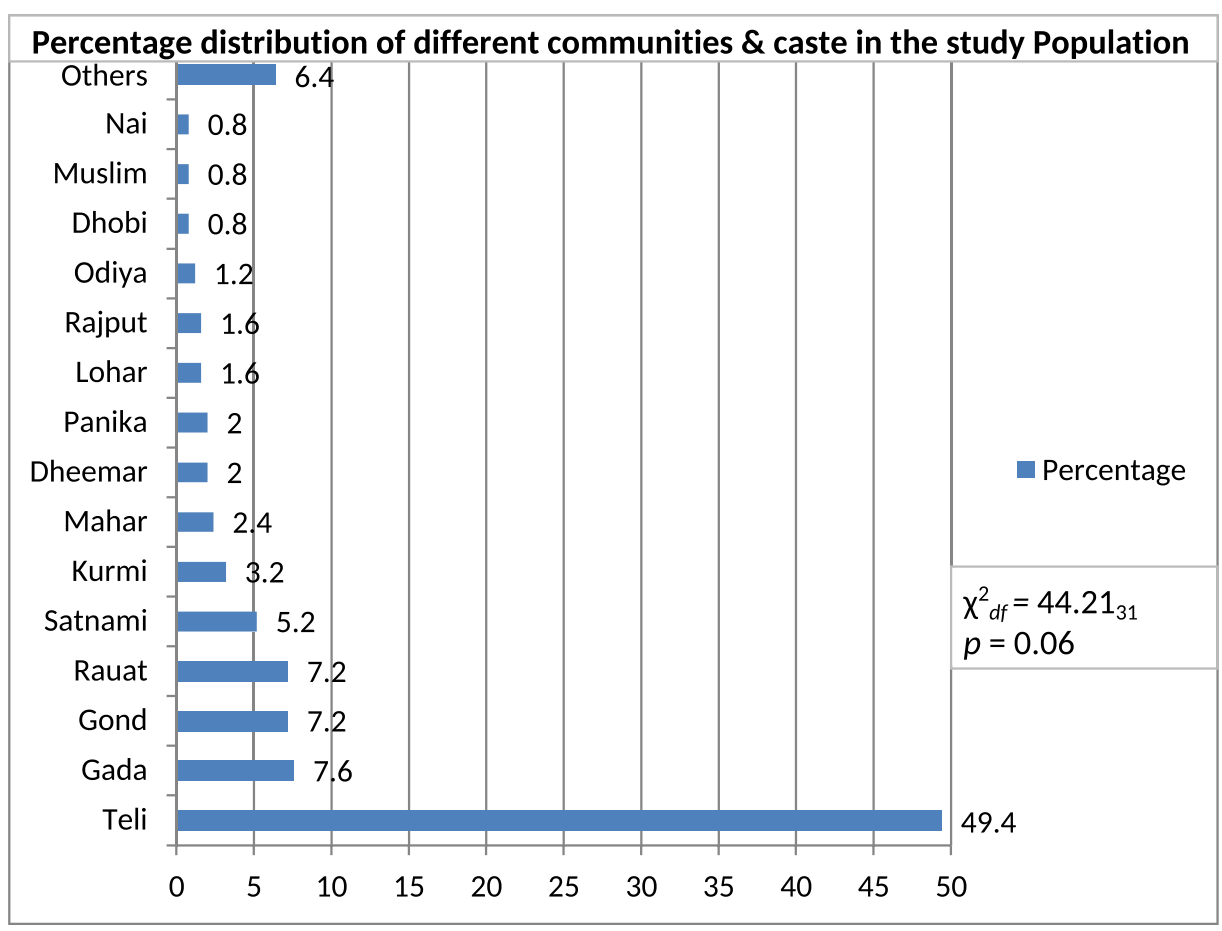

Fig. 1. Caste distribution among the study population $\chi_{2} \mathrm{df}=$ Chi-square with degree of freedom.

Table 1

General characteristics of the study groups.

\begin{tabular}{|c|c|c|c|c|c|c|}
\hline \multirow[t]{2}{*}{ Category } & \multirow{2}{*}{$\begin{array}{l}\text { SCT } \\
\mathrm{N}= \\
218 \\
\mathrm{n}\end{array}$} & & \multirow{2}{*}{$\begin{array}{l}\text { SCD } \\
\mathrm{N}= \\
31 \\
\mathrm{n}\end{array}$} & & \multirow[t]{2}{*}{$\chi^{2} \mathrm{df}$} & \multirow[t]{2}{*}{$p$-value } \\
\hline & & $(\%)$ & & $(\%)$ & & \\
\hline \multicolumn{7}{|l|}{ Age } \\
\hline$\leq 10$ years & 96 & 44 & 14 & 45.2 & $0.014_{1}$ & 0.91 \\
\hline$>10$ years & 122 & 56 & 17 & 54.8 & & \\
\hline \multicolumn{7}{|l|}{ Gender } \\
\hline Female & 116 & 53.2 & 21 & 67.7 & $2.32_{1}$ & 0.13 \\
\hline Male & 102 & 46.8 & 10 & 32.3 & & \\
\hline \multicolumn{7}{|l|}{ Weight (in Percentile) } \\
\hline $25-75$ & 82 & 37.6 & 2 & 6.5 & $14.81_{2}$ & $0.001 *$ \\
\hline Below 25 & 126 & 57.8 & 29 & 93.5 & & \\
\hline Above 75 & 10 & 4.6 & 0 & 0 & & \\
\hline \multicolumn{7}{|l|}{ Height (in Percentile) } \\
\hline $25-75$ & 89 & 40.8 & 2 & 6.5 & $17.22_{2}$ & $<0.001^{*}$ \\
\hline Below 25 & 111 & 50.9 & 28 & 90.3 & & \\
\hline Above 75 & 18 & 8.3 & 1 & 3.2 & & \\
\hline \multicolumn{7}{|l|}{ BMI (in Percentile) } \\
\hline Normal $(>25 \&<75)$ & 108 & 49.5 & 9 & 29.0 & $12.51_{3}$ & $0.006^{*}$ \\
\hline Below 10 & 40 & 18.3 & 14 & 45.2 & & \\
\hline Between 10 and 25 & 63 & 28.9 & 8 & 25.8 & & \\
\hline Above/equal to 75 & 7 & 3.2 & 0 & 0 & & \\
\hline \multicolumn{7}{|l|}{ Anemia Grade } \\
\hline No $(>11 \mathrm{Gm} / \mathrm{dL})$ & 82 & 37.6 & 4 & 12.9 & $7.3_{2}$ & $0.026^{*}$ \\
\hline $\begin{array}{l}\text { Mild to Moderate } \\
\qquad(7-11 \mathrm{Gm} / \mathrm{dL})\end{array}$ & 126 & 57.8 & 25 & 80.6 & & \\
\hline Severe $(<7 \mathrm{Gm} / \mathrm{dL})$ & 10 & 4.6 & 2 & 6.5 & & \\
\hline
\end{tabular}

$\chi 2$ df denotes Chi-square value with degree of freedom.

* Significant at $\mathrm{p}<0.05$.

(12.2\%), Gond (10.2\%), Satnami (8.2\%), Mahar (6.1\%) and Rajput (4.1\%). The frequency of 677TT was quite rare when compared to that of $1298 \mathrm{CC}$. The numbers (n\%) was found empty in many cells. Hence, to have a better picture of the distribution of the polymorphisms, the allelic and haplotypic distribution was determined among the different caste and communities and presented in Figs. 3 and 4. The distribution of the alleles in the children of the study population was very much homogenous (C vs T $\chi_{\text {df }}^{2}=23.81_{91}, \mathrm{p}=0.82$ and $\mathrm{A}$ vs C $\chi_{\mathrm{df}}^{2}=33.63_{91}, \mathrm{p}=$ 0.34 ). The mutant $677 \mathrm{~T}$ allele proportions were relatively greater than its contemporary wild allele $677 \mathrm{C}$ in Gond (12\% vs 6.4\%), Rauat $(9.3 \%$ vs $6.9 \%$ ) and Kurmi (4\% vs 3.1\%). In other castes like Dheemar, Panika, Rajput, Muslims, Nai, Vatrakar, Kewat, Sarthi, Kol depicted higher percentages of $677 \mathrm{~T}$ alleles and most of them were heterozygous variants. Similarly, the frequency of mutant $1298 \mathrm{C}$ allele was observed to be greater than wild allele $1298 \mathrm{~A}$ in Gond ( $8.6 \%$ vs $6.1 \%$ ), Rauat $(8.6 \%$ vs $6.1 \%)$, Satnami (6.8\% vs $4 \%$ ) and Mahar (3.6\% vs $1.4 \%)$. Rest of the castes depicted nearly equal percentages of both alleles.

The frequency of haplotypic population were also found comparable within the different castes $\left(\chi_{\mathrm{df}}^{2}=114.54_{93}, \mathrm{p}=0.06\right)$. The frequency of combined wild haplotype (677C/1298A) was $51.9 \%$ and that of mutant haplotype (677T/1298C) was $41.9 \%$ in Teli children (Fig. 4). The mutant haplotypes frequency was greater in Gond (14.5\%), Ganda (9.7\%), Rauat $(8.1 \%)$ and Satnami $(6.4 \%)$ when compared to other castes. The frequency of the mutant form was observed to be higher in Muslims, Vatrakar and Sarthi communities.

\subsection{Comparison of variables among the three genotypes of MTHFR C677T and A1298C SNPs}

The mean (SD) comparison among the genotypes is tabulated in Table 3. Mean (SD) of the variables did not reveal significant differences among the three genotypic forms of C677T. Contrary to it, all the variables depicted significant variations in A1298C SNP genotypes. The mean age $(\mathrm{p}=0.001)$, weight $(\mathrm{p}<0.001)$, height $(\mathrm{p}<0.001)$, BMI $(\mathrm{p}<$ $0.001)$ and hemoglobin concentration $(\mathrm{p}=0.002)$ were lower in homozygous mutant children.

\subsection{Association of genotypes with general characteristics of the children}

As shown in Table 4, A1298C showed significant differences between the two age groups $(\mathrm{p}=0.02) .80 \%$ and $59.2 \%$ of the homozygous mutants were below 10 years. None of the genotypes revealed gender preferences in the study population $(\mathrm{p}=0.78)$. The variables like 


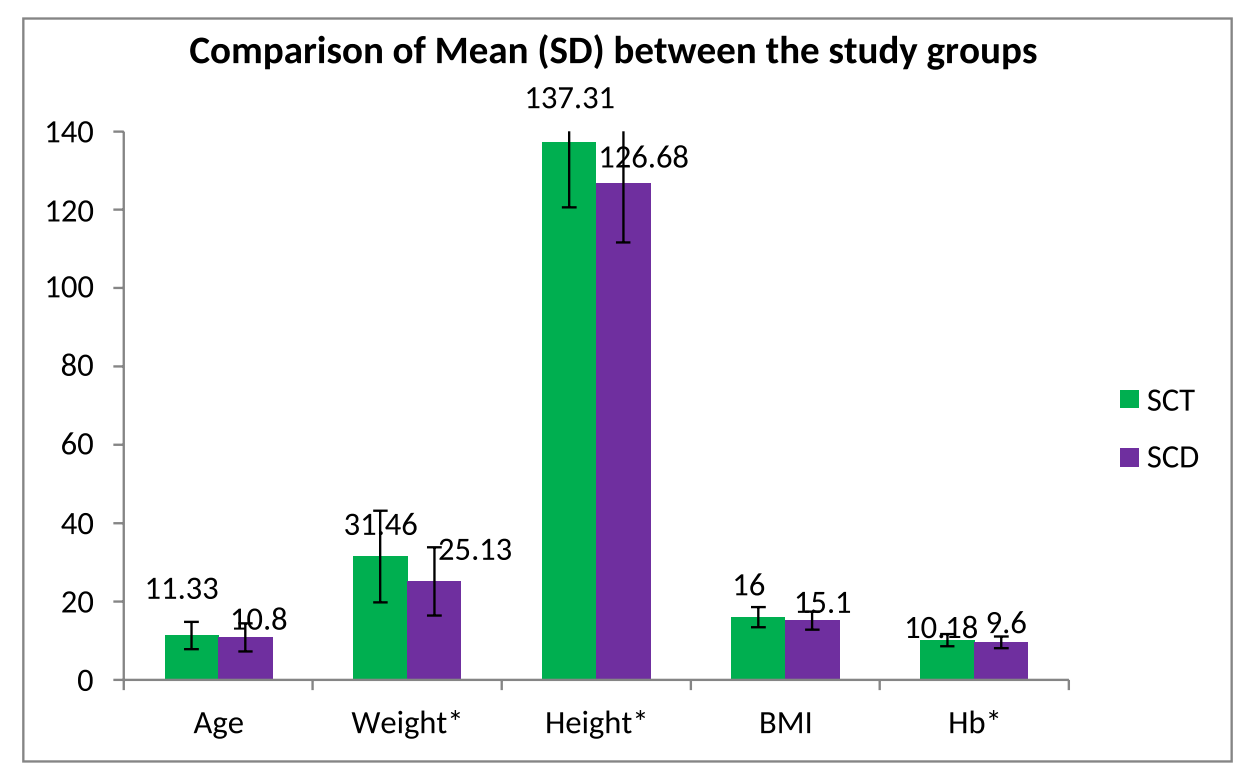

Fig. 2. Comparison of Mean (SD) of the quantitative variables between the two study groups *Significant at $\mathrm{p}<0.05$.

Table 2

Distribution of MTHFR C677T and A1298C genotypes in the study population and their association within the groups.

\begin{tabular}{|c|c|c|c|c|}
\hline \multicolumn{5}{|c|}{ Genotype distribution } \\
\hline \multirow{3}{*}{$\begin{array}{l}\text { Total } \\
\text { Population } \\
\mathrm{N}=249\end{array}$} & SCT & SCD & \multirow[t]{3}{*}{$\chi_{d f}^{2}, p$-value } & \multirow[t]{3}{*}{ OR (95\%CI) } \\
\hline & $N=218$ & $\mathrm{~N}=31$ & & \\
\hline & $\mathrm{n}(\%)$ & $\mathrm{n}(\%)$ & & \\
\hline \multicolumn{5}{|l|}{ C677T n(\%) } \\
\hline $\begin{array}{l}\text { CC } \\
179(71.9)\end{array}$ & $\begin{array}{l}161 \\
(73.9)\end{array}$ & $\begin{array}{l}18 \\
(58.1)\end{array}$ & $3.36_{2}, 0.19$ & Reference \\
\hline $\begin{array}{l}\text { CT } \\
\qquad 65(26.1)\end{array}$ & $53(24.3)$ & $\begin{array}{l}12 \\
(38.7)\end{array}$ & $\begin{array}{l}3.1_{1}, 0.05 \text { (CT vs } \\
\text { CC) }\end{array}$ & $2.02(.89-4.48)$ \\
\hline $\begin{array}{l}\text { TT } \\
5(2.0)\end{array}$ & $4(1.8)$ & $1(3.2)$ & $\begin{array}{l}.52_{1}, 0.23 \text { (TT vs } \\
\text { CC) }\end{array}$ & $\begin{array}{l}2.22 \\
(.08-18.82)\end{array}$ \\
\hline \multicolumn{5}{|c|}{ A1298C n(\%) } \\
\hline $\begin{array}{l}\text { AA } \\
\quad 77(30.9)\end{array}$ & $72(33)$ & $5(16.1)$ & $5.15_{2}, 0.08$ & Reference \\
\hline $\begin{array}{l}\mathrm{AC}^{\prime} \\
\qquad 123(49.4)\end{array}$ & $\begin{array}{l}102 \\
(46.8)\end{array}$ & $\begin{array}{l}21 \\
(67.7)\end{array}$ & $\begin{array}{l}4.7_{1}, 0.02 *\left(\mathrm{AC}^{\prime} \text { vs }\right. \\
\mathrm{AA})\end{array}$ & $\begin{array}{l}2.95 \\
(1.11-9.15)\end{array}$ \\
\hline $\begin{array}{l}\text { C'C' } \\
\quad 49(19.7)\end{array}$ & $44(20.2)$ & $5(16.1)$ & $\begin{array}{l}.56_{1}, 0.22\left(C^{\prime} C^{\prime} \text { vs }\right. \\
\text { AA) }\end{array}$ & $\begin{array}{l}1.63 \\
(0.41-6.38)\end{array}$ \\
\hline
\end{tabular}

$\mathrm{n}(\%)$ denotes number of children with the column percentage. $\chi^{2}$ df denotes Chi-square value with degree of freedom.

OR(95\%CI) denotes odds ratio with 95\% confidence interval.

*Significant at $\mathrm{p}<0.05$.

weight, height and BMI were comparable among the three genotypes of C677T. In contrast, children with 1298AA, 1298AC and 1298CC depicted significant differences in weight $(\mathrm{p}=0.004)$ and BMI $(\mathrm{p}<$ 0.001 ) but not height ( $\mathrm{p}=0.72$ ). $60 \%$ of children with $677 \mathrm{TT}$ variant had BMI below 10th percentile while approximately $43 \%$ of $1298 \mathrm{CC}$ children were below 10th percentile. A1298C polymorphism revealed significant association $(\mathrm{p}=0.001)$ for different grades of anemia unlike the children with C677T genotypes ( $\mathrm{p}=0.49$ ). Nearly $81 \%$ children of 1298CC and $60 \%$ children of 677TThad mild to moderate degree anemia. Anemia of severe grade was seen in $20 \%$ of $677 \mathrm{TT}$ children and in $2 \%$ of $1298 C$ C genotypic children.

\section{Discussions}

Altered or reduced enzyme activity due to mutation in the MTHFR gene, results in homocysteinemia that further accelerates the pathophysiology of vascular crisis associated in sickle cell hemoglobinopathy. ${ }^{2,7}$ It is therefore highly essential to identify these genetic markers in order to identify the high risk individuals who have co-existence of these SNPs along with sickle cell gene. Currently, there are insufficient national data regarding the distribution of both the MTHFR SNPs, especially in sickle cell anemia. Hence, to understand the geographical and ethnic distributions and the interactions of these genotypes and alleles would be of utmost importance in areas with high prevalence of sickle cell gene.

This study was a hospital based study conducted on 249 children with sickle cell gene. BMI of nearly $70 \%$ of children was below 25th percentile in the SCD group and more than $90 \%$ presented with anemia (Table 1). Hemoglobin and anthropometric indices were significantly lower in this group (Fig. 2). Theses finding corroborated with Helvaci et al. study showed significantly low weight and BMI in SCD individuals as compared to HbAA controls, but not so in height. ${ }^{8}$ Similarly, various other studies indicated impaired growth being quite common in children with SCD. Poor nutritional status, repeated events of hemolytic crisis leading to frequent hospitalization mainly account for anemia and impaired growth in homozygous disease cases as compared to heterozygous trait group. ${ }^{9,10}$ Low hemoglobin concentration and homocysteinemia are more prevalent in homozygous cases as reported in various article. $^{2,11}$

Although, it is a hospital based study, it could be considered as a foremost step to document the frequencies of C677T and A1298C polymorphisms in this area. Various studies depicted a much varied frequencies of $\mathrm{C677T}$ genotypes which are studied more frequently in comparison to A1298C. ${ }^{12}$ The reason might reside in the fact that the enzyme activity of homozygous 677TT variant is reduced by nearly 70\% and that of $1298 \mathrm{CC}$ by $40 \%$ and hence, the former is supposed to have greater clinical impact than the later though not well documented. ${ }^{13-15}$ Indian Genome Variation Consortium identified 3\% of prevalence of 677TT variant in India, highest being in North India followed by South India. The distribution was equally rare in Eastern and Western parts and nearly negligible in Central India. ${ }^{16}$ Angeline et al. study presented a prevalence of $1.38 \%$ 677TT and 18.1\% 677CT in 72 South-Indian individuals. The frequency percentages of 1298AC and 1298CC were $47.2 \%$ and $15.3 \%$ respectively. ${ }^{7}$ Similarly, few other studies in North India, attributed frequency percentage of $1.9 \%-4.8 \%$ 677TT and $3 \%-$ $20.8 \% 1298 C$ C. 3,17 In general, the frequency of homozygous mutant 1298CC is more prevalent globally that homozygous 677TT. The 


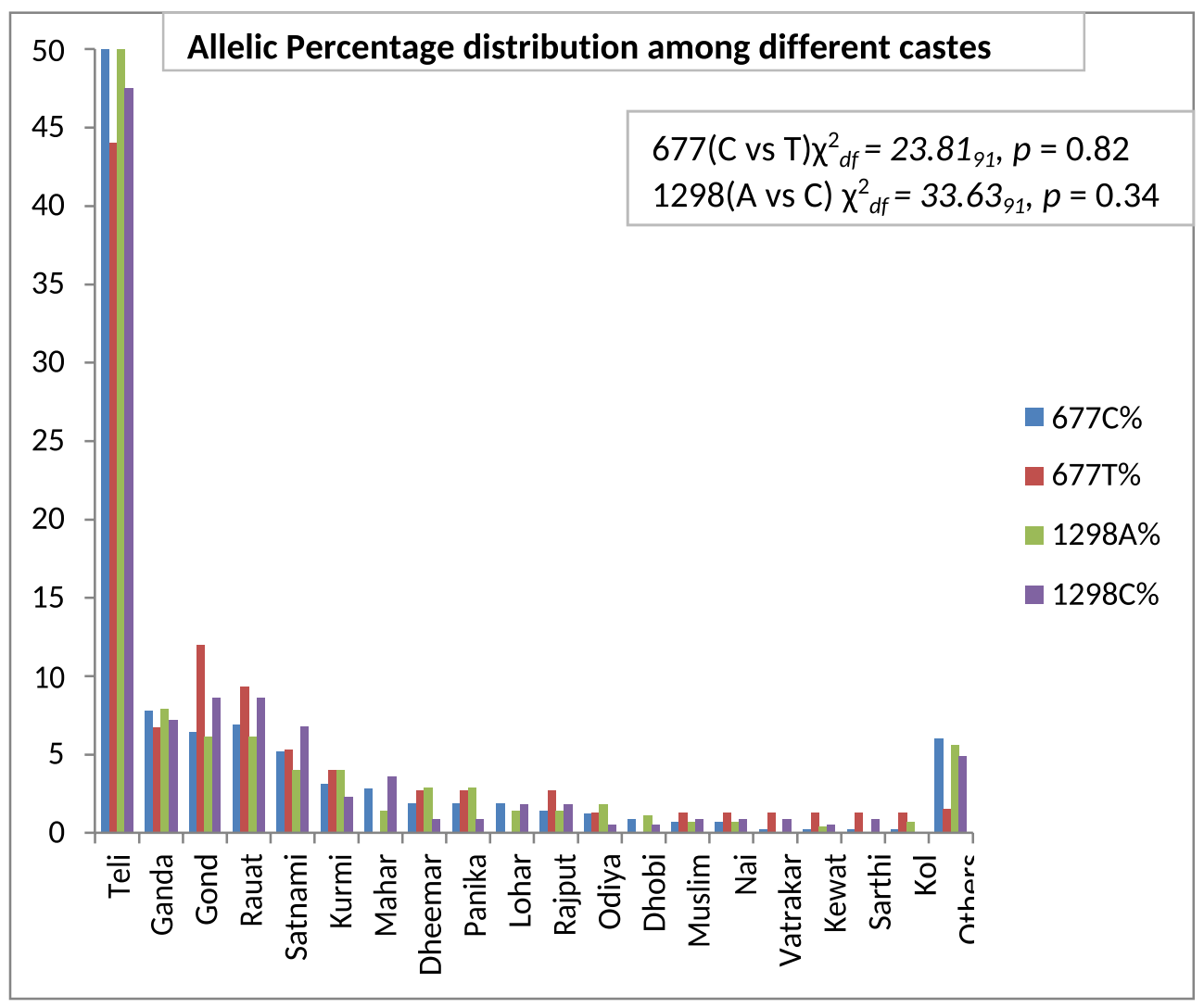

Fig. 3. Graphical representation of allelic distribution among different castes of the study population $\chi^{2}$ df denotes Chi-square value with degree of freedom.

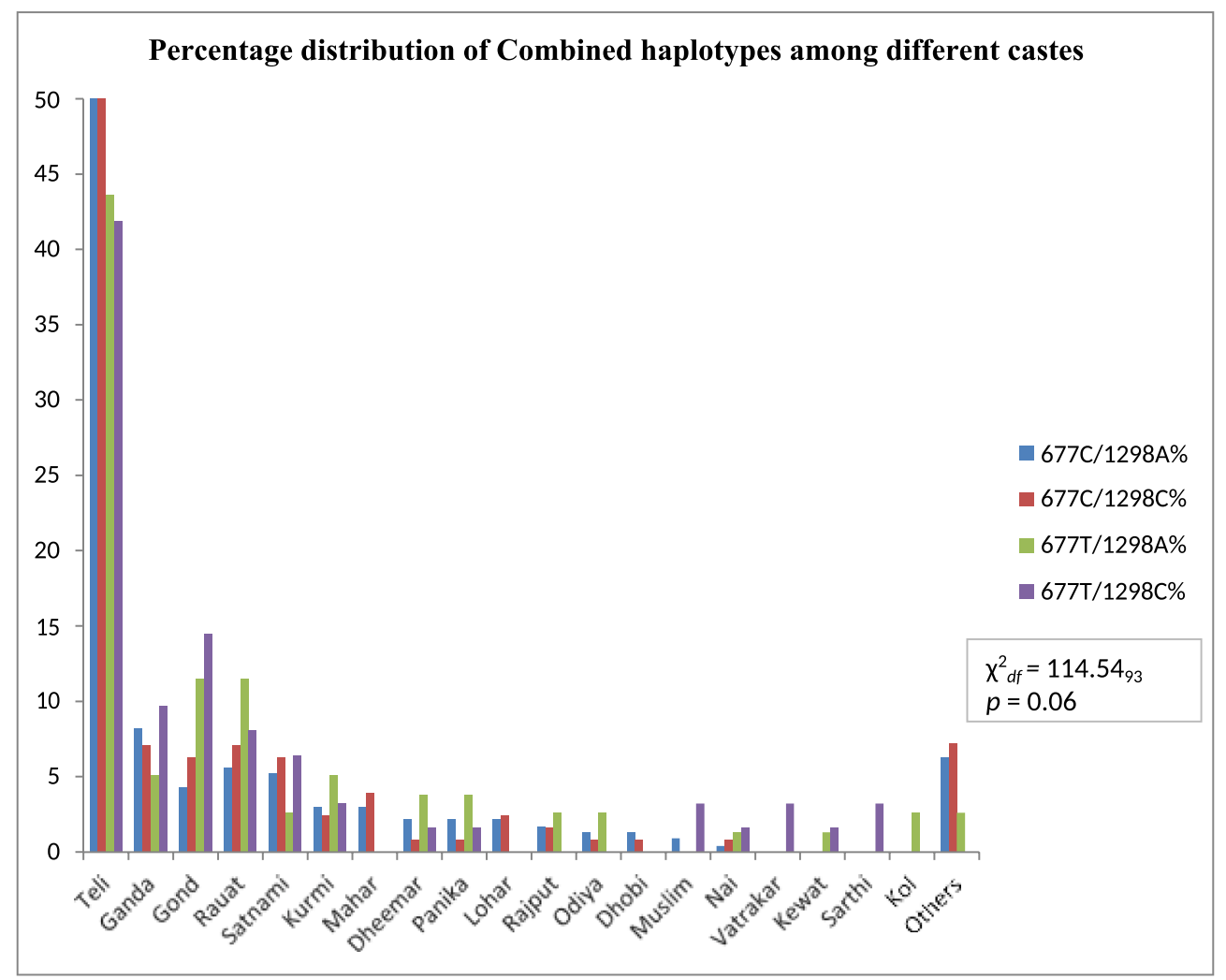

Fig. 4. Graphical representation of distribution of combined haplotypes among different castes of the study population $\chi^{2} \mathrm{df}$ denotes Chi-square value with degree of freedom. 
Table 3

Comparison of mean (SD) of the variables between the three genotypic forms of MTHFR C677T and A1298C.

\begin{tabular}{llll}
\hline C677T & & & \\
\hline Variables & CC & CT & TT \\
& 179 & 65 & 5 \\
\hline Age (years) & 11.15 & $11.75(3.78)$ & $9.4(2.3)$ \\
Weight (Kg) & $(3.37)$ & & \\
& 30.29 & $32.25(12.49)$ & $23.8(11.65)$ \\
Height (cm) & $(11.18)$ & & \\
& 135.31 & $138.49(17.26)$ & $20.16(9.01)$ \\
BMI & $(16.53)$ & & $13.88(1.8)$ \\
Hemoglobin (G/ & $15.9(2.49)$ & $16.04(2.74)$ & $9(2)$ \\
dL) & $10.2(1.51)$ & $9.9(1.5)$ & \\
A1298C & & & CC \\
Variables & AA & AC & 49 \\
Age (years) & 77 & 123 & $10.04(3.12), p=0.001^{*}$ \\
Weight (Kg) & $(3.46)$ & $0.025^{*}$ & \\
Height (cm) & 34.71 & $30.13(11.13)$, & $25.67\left(10.36, p<0.001^{*}\right.$ \\
BMI & $(11.71)$ & $\mathrm{P}=0.014^{*}$ & \\
Hemoglobin (G/ & 141.92 & $134.7(16.15)$, & $129.88(15.98), p<$ \\
dL) & $(16.76)$ & $\mathrm{P}=0.007^{*}$ & $0.001^{*}$ \\
\hline
\end{tabular}

*Significant at $\mathrm{p}<0.05$ when compared with the wild genotype.

^ Significant at $\mathrm{p}<0.05$ when compared between the heterozygous and mutant variants. genotypic frequency 677TT ranged from nearly zero percent in Western and Eastern population to 5\%-10\% in South and North Indians, with an average of $2.16 \%$. Frequency of $677 \mathrm{CC}$ was found to be more homogenously distributed throughout the country that ranged from zero percent in some North Eastern population to $25 \%$ with an average of $19.46 \%{ }^{3}$ The genetic frequencies exhibited by C677T and A1298C SNPs in our study were in agreement to the above findings with a prevalence of $26.1 \%, 2.0 \%, 49.4 \%$ and $19.7 \%$ for $677 \mathrm{CT}, 677 \mathrm{TT}, 1298 \mathrm{AC}$ and $1298 \mathrm{CC}$ respectively (Table 2 ).

The caste wise distribution (Fig. 1) of children with sickle cell disorder in our study population was somewhat different to that reported by Patra et al. which was a community based screening accomplished on 359,823 subjects in Raipur District of Chhattisgarh. ${ }^{4}$ The frequency of the sickle cell gene observed in the community was highest for Ghasia (24\%) followed by Ganda (22\%), Agharia (19\%), Kolta (17\%), Kurmi and Halba (16\%), Teli (15\%), Gond (13\%), Binjhwar (11\%) and Kumhar (10\%). The study was a community based screening and included a large sample size of varied castes and communities even from remote sub-divisional areas of the district. The difference in caste distribution was because of the variations in community inflow to the hospital from nearby or approachable urban and rural catchment areas.

Distribution of all the four alleles and combined haplotypes was quite homogenous among the different castes (Figs. 3 and 4). Only a few studies have reported the geographical and ethnic distribution of the MTHFR genotypes and alleles in India. Higher frequency has been observed for 677T allele in Rajputs' (7.8\%) and Sindhi $(23.8 \%)$ but absent or lower frequency in tribal populations such as Kom, Thadou and Munda. The frequency of 677T alleles in Haryanas' Ahirs and Jats was respectively $3 \%$ and $6 \% .{ }^{18}$ Number of children representing from communities other than Teli was very less so as to provide an accurate data of genotypic prevalence. Yet, this study would be one of its kinds to

Table 4

Association of the C677T and A1298C' genotypes with the general characteristics of the children in study population.

\begin{tabular}{|c|c|c|c|c|c|c|c|c|}
\hline \multirow[t]{4}{*}{ Category } & \multicolumn{4}{|c|}{ C677T Genotypes } & \multicolumn{4}{|c|}{ A1298C Genotypes } \\
\hline & \multirow{3}{*}{$\begin{array}{l}\mathrm{CC} \\
179 \\
\mathrm{n}(\%)\end{array}$} & \multirow{3}{*}{$\begin{array}{l}\mathrm{CT} \\
65 \\
\mathrm{n}(\%)\end{array}$} & \multirow{3}{*}{$\begin{array}{l}\mathrm{TT} \\
5 \\
\mathrm{n}(\%)\end{array}$} & \multirow[t]{2}{*}{$\chi^{2} \mathrm{df}, p$-value } & \multirow{2}{*}{$\begin{array}{l}\text { AA } \\
77\end{array}$} & \multirow{2}{*}{$\begin{array}{l}\text { AC } \\
123\end{array}$} & \multirow{2}{*}{$\begin{array}{l}\text { CC } \\
49\end{array}$} & \multirow[t]{3}{*}{$\chi^{2} \mathrm{df}, p$ - value } \\
\hline & & & & & & & & \\
\hline & & & & & $\mathrm{n}(\%)$ & $\mathrm{n}(\%)$ & $\mathrm{n}(\%)$ & \\
\hline \multicolumn{9}{|l|}{ Age } \\
\hline$\leq 10$ years & $80(44.7)$ & $26(40)$ & $4(80)$ & $\begin{array}{l}3.08_{2}, \\
0.21\end{array}$ & $26(33.8)$ & $55(44.7)$ & $29(59.2)$ & $\begin{array}{l}7.87_{2} \\
0.02^{*}\end{array}$ \\
\hline$>10$ years & $99(55.3)$ & $39(60)$ & $1(20)$ & & $51(66.2)$ & $68(55.3)$ & $20(40.8)$ & \\
\hline \multicolumn{9}{|l|}{ Gender } \\
\hline Female & $97(54.2)$ & $37(56.9)$ & $3(60)$ & $\begin{array}{l}0.19_{2}, \\
0.91\end{array}$ & $42(54.5)$ & $70(56.9)$ & $25(51)$ & $\begin{array}{l}0.5_{2} \\
0.78\end{array}$ \\
\hline Male & $82(45.8)$ & $28(43.1)$ & $2(40)$ & & $35(45.5)$ & $53(43.1)$ & 24(49) & \\
\hline \multicolumn{9}{|l|}{ Weight (in Percentile) } \\
\hline $25-75$ & $62(34.6)$ & $21(32.3)$ & $1(20)$ & $\begin{array}{l}1.76_{4}, \\
0.78\end{array}$ & $35(45.5)$ & $43(35)$ & $6(12.2)$ & $\begin{array}{l}15.52^{4} \\
0.004^{*}\end{array}$ \\
\hline Below 25 & $111(62)$ & $40(61.5)$ & $4(80)$ & & $40(51.9)$ & $74(60.2)$ & 41(83.7) & \\
\hline Above 75 & $6(3.4)$ & $4(6.2)$ & $0(0)$ & & $2(2.6)$ & $6(4.9)$ & $2(4.1)$ & \\
\hline \multicolumn{9}{|l|}{ Height (in Percentile) } \\
\hline $25-75$ & $67(37.4)$ & $24(36.9)$ & $0(0)$ & $\begin{array}{l}3.86_{4}, \\
0.43\end{array}$ & $32(41.6)$ & $44(35.8)$ & $15(30.6)$ & $\begin{array}{l}2.07_{4} \\
0.72\end{array}$ \\
\hline Below 25 & $100(55.9)$ & $35(53.8)$ & $4(80)$ & & $39(50.6)$ & $69(56.1)$ & $31(63.3)$ & \\
\hline Above 75 & $12(6.7)$ & $6(9.2)$ & $1(20)$ & & $6(7.8)$ & $10(8.1)$ & $3(6.1)$ & \\
\hline \multicolumn{9}{|l|}{ BMI (in Percentile) } \\
\hline Normal $(>25 \&<75)$ & $89(49.7)$ & $28(43.1)$ & $0(0)$ & $10.59_{6}, 0.10$ & $50(64.9)$ & $63(51.2)$ & $4(8.2)$ & $\begin{array}{l}45.79_{6} \\
<0.001\end{array}$ \\
\hline Below 10 & $34(19)$ & $17(26.2)$ & $3(60)$ & & $11(14.3)$ & $22(17.9)$ & $21(42.9)$ & \\
\hline Between 10 and 25 & $49(27.4)$ & $20(30.8)$ & $3(40)$ & & $16(20.8)$ & $35(28.5)$ & $20(40.8)$ & \\
\hline Above/equal to 75 & $7(3.9)$ & $0(0)$ & $0(0)$ & & $0(0)$ & $3(2.4)$ & $4(8.2)$ & \\
\hline \multicolumn{9}{|l|}{ Anemia Grade } \\
\hline No $(>11 \mathrm{gm} / \mathrm{dL})$ & $65(36.3)$ & $20(30.8)$ & $1(20)$ & $\begin{array}{l}3.41_{4}, \\
0.49\end{array}$ & $30(39)$ & $48(39)$ & $8(16.3)$ & $\begin{array}{l}17.97_{4} \\
0.001^{*}\end{array}$ \\
\hline Mild to Moderate (7-11 gm/dL) & $106(59.2)$ & $42(64.6)$ & $3(60)$ & & $39(50.6)$ & $72(58.5)$ & $40(81.6)$ & \\
\hline Severe $(<7 \mathrm{Gm} / \mathrm{dL})$ & $8(4.5)$ & $3(4.6)$ & $1(20)$ & & $8(10.4)$ & $3(2.4)$ & $1(2.0)$ & \\
\hline
\end{tabular}

$\mathrm{n}(\%)$ denotes number of children with the column percentage.

$\chi 2 \mathrm{df}$ denotes Chi-square value with degree of freedom.

*Significant at $\mathrm{p}<0.05$. 
provide an insight to the distribution pattern expected in our population. Impact of dietary factors is considered another aspect and it is hypothesized that an increase consumption of dietary folate might have enabled higher frequency of MTHFR 677TT in European population and low folic acid intake in Indian population might have influenced lower frequency of homozygous 677TT. ${ }^{18,19}$ The said hypotheses although not proved yet, but it is definitely suggestive of impact of food habits and socio-cultural rituals on genetic selection of the seen mutations.

Genotype A1298C depicted age preferences unlike C677T ( $\mathrm{p}=0.02)$. The homozygous mutant genotypes recorded lowered mean age and percentages of children attending hospital with some sort of complaints in below 10 years age group was more(Tables 3 and 4). This could be ascribed to the fact that children with mutant variants might be having clinical complications at an early age as compared to those with wild genotypes. Devi et al. study reported that females showed up a higher $\mathrm{T}$ allele frequency $(15.5 \%)$ than the males $(5.5 \%)$ with OR of $2.67, \mathrm{p}>$ 0.05 . $^{20}$ The gender differences were insignificant in our population although female depicted higher percentages in either of the mutant variants. This might be due to the fact that total female children were more than male children in the study population.

Reduced MTHFR enzyme activity markedly alter B12 and folic acid metabolism leading to megaloblastic blood indices. Concomitant presence of anemia and homocystenemia are well associated with frequent vascular crisis which often lead to altered physical growth of the child particularly in homozygous SCD cases. ${ }^{21-23}$ Present study showed significant association of A1298C with BMI and anemia grades ( $\mathrm{p}=0.001)$. Children with A1298C variants also depicted lower mean for hemoglobin and anthropometric metrics (Table 3). These children should undergo frequent follow-up to identify the crisis event at an early stage. In such cases the conventional dose of folic acid might not be sufficient to meet the increasing demand of these vitamins. Rather, active forms of folate such as 5-methyl folate needs to be replaced with folic acid. ${ }^{24}$ Although the present study has certain limitations like small size population, and being a hospital based study, yet the ethnic based distribution of the SNPs can be utilized for understanding the gene interactions in sickle cell hemoglobinopathy cases in this area.

\section{Conclusion}

The study revealed the fact that concomitant existence of MTHFR SNPs with sickle cell gene is common in this area. Evaluation for homozygous mutant genetic markers becomes essential especially in children with SCD who frequently get hospitalized for vascular complications. Further, large scale community based studies would definitely be valuable to gather more accurate information regarding such interactions.

\section{CRediT authorship contribution statement}

Suprava Patel: Conceptualization, Validation, Formal analysis, Investigation, Resources, Data acquisition, Data analysis, Statistical analysis, Writing - original draft, Project administration, Funding acquisition. Rachita Nanda: Conceptualization, Data acquisition, Statistical analysis, Writing - review \& editing, Supervision. Nighat Hussain: Validation, Investigation, Data acquisition, Data analysis, Writing review \& editing. Eli Mohapatra: Conceptualization, Design, Methodology, Validation, Writing - original draft, Writing - review \& editing, Visualization. Pradeep K. Patra: Conceptualization, Design, Methodology, Validation, Writing - original draft, Writing - review \& editing, Visualization, Supervision.

\section{Declaration of competing interest}

No potential conflict of interest relevant to this article was reported.

\section{Acknowledgement}

The study was funded by Chhattisgarh Council of Science and Technology, Raipur, Chhattisgarh, India.

\section{References}

1 Jain D, Italia K, Sarathi V, Ghoshand K, Colah R. Sickle cell anemia from central India: a retrospective analysis. Indian Pediatr. 2012 Nov;49(11):911-913.

2 Nishank SS, Singh MPSS, Yadav R. Clinical impact of factor V Leiden, prothrombin G20210A, and MTHFR C677T mutations among sickle cell disease patients of Central India. Eur J Haematol. 2013 Nov;91(5):462-466.

3 Kumar J, Das SK, Sharma P, Karthikeyan G, Ramakrishnan L, Sengupta S. Homocysteine levels are associated with MTHFR A1298C polymorphism in Indian population. J Hum Genet. 2005;50(12):655-663.

4 Patra PK, Chauhan VS, Khodiar PK, Dalla AR, Serjeant GR. Screening for the sickle cell gene in Chhattisgarh state, India: an approach to a major public health problem. J Community Genet. 2011 Sep;2(3):147-151.

5 el-Hazmi MA. Clinical and haematological diversity of sickle cell disease in Saudi children. J Trop Pediatr. 1992;38(3):106-112.

6 Hu Z, Chang SM, Younis R, Alvarez OA. Optimal hemoglobin level for pediatric sickle cell patients who undergo adenotonsillectomy. Blood. 2018 Nov 29;132(suppl 1), 4938-4938.

7 Angeline T, Jeyaraj N, Granito S, Tsongalis G. Prevalence of MTHFR gene polymorphisms (C677T and A1298C) among Tamilians. Exp Mol Pathol. 2004.

8 Helvaci MR, Kaya H. Effect of sickle cell diseases on height and weight. Pak J Med Sci. 2011;27(2):1-4.

9 Lukusa Kazadi A, Ngiyulu RM, Gini-Ehungu JL, Mbuyi-Muamba JM, Aloni MN. Factors associated with growth retardation in children suffering from sickle cell anemia: first report from central africa. Anemia. 2017;2017:7916348.

10 Odetunde OI, Chinawa JM, Achigbu KI, Achigbu EO. Body mass index and other anthropometric variables in children with sickle cell anaemia. Pak J Med Sci. 2016;32 (2):341-346.

11 Jain D, Bagul AS, Shah M, Sarathi V. Morbidity pattern in hospitalized under five children with sickle cell disease. Indian J Med Res. 2013 Sep;138(3):317-321.

12 Sinha E, Walia GK, Mukhopadhyay R, et al. Methylenetetrahydrofolate reductase polymorphism: an independent risk determinant of coronary heart disease in an endogamous population from Delhi (India). e-SPEN, Eur e-J Clin Nutr Metab. 2010 Oct 1;5(5):e213-e218.

13 van der Put NM, Gabreëls F, Stevens EM, et al. A second common mutation in the methylenetetrahydrofolate reductase gene: an additional risk factor for neural-tube defects? Am J Hum Genet. 1998 May;62(5):1044-1051.

14 Weisberg I, Tran P, Christensen B, Sibani S, Rozen R. A second genetic polymorphism in methylenetetrahydrofolate reductase (MTHFR) associated with decreased enzyme activity. Mol Genet Metabol. 1998 Jul;64(3):169-172.

15 Yang B, Liu Y, Li Y, et al. Geographical distribution of MTHFR C677T, A1298C and MTRR A66G gene polymorphisms in China: findings from 15357 adults of Han nationality. PloS One. 2013;8(3), e57917.

16 Indian Genome Variation Consortium. Genetic landscape of the people of India: a canvas for disease gene exploration. J Genet. 2008 Apr 1;87(1):3-20.

17 Butler S, Young A, Akam EC, Sinha N, Agrawal S, Mastana S. Association of methylenetetrahydrofolate reductase (MTHFR) C677T and A1298C polymorphisms with coronary artery disease (CAD) in a North Indian population. Cogent Medicine. 2018 Jan 1;5(1):1478477.

18 Saraswathy KN, Asghar M, Samtani R, et al. Spectrum of MTHFR gene SNPs C677T and A1298C: a study among 23 population groups of India. Mol Biol Rep. 2012 Apr 1; 39(4):5025-5031.

19 Wang X, Fu J, Li Q, Zeng D. Geographical and ethnic distributions of the MTHFR C677T, A1298C and MTRR A66G gene polymorphisms in Chinese populations: a meta-analysis. PloS One. 2016 Apr 18;11(4), e0152414.

20 Devi ARR, Govindaiah V, Ramakrishna G, Naushad SM. Prevalence of methylene tetrahydrofolate reductase polymorphism in South Indian population. Curr Sci. 2004; 86(3):440-443.

21 Al-Yassin A, Osei A, Rees D. Folic acid supplementation in children with sickle cell disease. Arch Dis Child. 2012 May 1;97(Suppl 1):A91-A92.

22 Dixit R, Nettem S, Madan SS, et al. Folate supplementation in people with sickle cell disease. Cochrane Database Syst Rev. 2016 Feb 16;2:CD011130.

23 Williams BA, McCartney H, Adams E, et al. Folic acid supplementation in children with sickle cell disease: study protocol for a double-blind randomized cross-over trial. Trials. 2020 Jun 29;21(1):593.

24 Shelton RC, Sloan Manning J, Barrentine LW, Tipa EV. Assessing effects of 1methylfolate in depression management: results of a real-world patient experience trial. Prim Care Companion CNS Disord. 2013;15(4). PCC.13m01520. 